\title{
Changes in ascorbic acid levels in apples of different varieties in the course of storage
}

\author{
K. A. BOGDAŃSKI, H. W. BOGDAŃSKA
}

\section{INTRODUCTION}

As reported in an earlier publication (1), ascorbic acid (AA) is distributed in ripe apples according to a specific gradient which varies somewhat with variety.

The authors believed it might be of interest to follow the changes this gradient undergoes during cold storage. The results of this study are given below.

\section{METHODS}

\section{Material}

The series of apples selected for examination included fruits of a more or less uniform size (diameters and weight given in the tables of results) and colour. A characteristic of the series is given in the Table. 1.

\section{Methods of determination of ascorbic acid}

The AA levels were determined in 20 cuts of each apple sliced according to a special system which allowed to establish precisely the location of each cut. Two opposite lying quarters of the apple were taken for analysis, one from the side most exposed to the sun and the other - its antipode. After cutting off the both top parts the quarter was sliced into ten cuts of determined thickness*, the periphery being counted as the first and the central part of the core as the tenth. This first cut denoted in the tables by „P" was cut as thin as possible, nevertheless it included besides the epidermis also some layers of parenchymal cells. Since even small deviations in the thickness

The thickness of the leayers, proportional to the size of the apple, different somewhat for the particular series. 
of this cut have a decisive influence on the results of analysis, therefore, for control, the weight-to-surface ratio (grammature) was also determined.

Table 1.

Characteristic of the series of apples selected for examination

\begin{tabular}{|c|c|c|c|c|}
\hline No. & Variety & Origin & $\begin{array}{l}\text { Date of placing } \\
\text { in cold store: } \\
4^{\circ} \text {-var. Ontario } \\
0^{\circ} \text {-other var. }\end{array}$ & Colour \\
\hline I & Boiken & $\begin{array}{l}\text { Private orchard } \\
\text { Jasnowski, Skierniewice }\end{array}$ & Oct. 13,1959 & \multirow[t]{2}{*}{$\begin{array}{l}\text { greenish, later } \\
\text { greenish-yellow } \\
\text { with slight blush }\end{array}$} \\
\hline II & Boiken & $\begin{array}{l}\text { Orchard of Pomological } \\
\text { Institute, Skierniewice }\end{array}$ & Oct. 10,1959 & \\
\hline III & Jonathan & $\begin{array}{l}\text { Orchard of Pomological } \\
\text { Institute, Dąbrowice }\end{array}$ & Oct. 10,1959 & $\begin{array}{l}\text { intensely red; on the } \\
\text { side least exposed to } \\
\text { sunrays green pat- } \\
\text { ches yellowing later }\end{array}$ \\
\hline IV & Kitajka & $\begin{array}{l}\text { Orchard of Pomological } \\
\text { Institute, Skierniewice }\end{array}$ & Oct. 2, 1959 & $\begin{array}{l}\text { greenish, later } \\
\text { greenish-yellow }\end{array}$ \\
\hline $\mathrm{V}$ & Ontario & $\begin{array}{l}\text { Orchard of Pomological } \\
\text { Institute, Skierniewice }\end{array}$ & Oct. 10,1959 & \multirow{2}{*}{$\begin{array}{l}\text { green, later greenish- } \\
\text {-yellow with extensive } \\
\text { blush }\end{array}$} \\
\hline VI & Ontario* & $\begin{array}{l}\text { Orchard of Pomological } \\
\text { Institute, Skierniewice }\end{array}$ & Oct. 10,1959 & \\
\hline VII & $\begin{array}{l}\text { Yellow } \\
\text { Belflower }\end{array}$ & $\begin{array}{l}\text { Orchard of Pomological } \\
\text { Institute, Dąbrowice }\end{array}$ & Sept. 24,1959 & \multirow{2}{*}{$\begin{array}{l}\text { greenish, later } \\
\text { greenish-yellow with } \\
\text { blush }\end{array}$} \\
\hline VIII & $\begin{array}{l}\text { Yellow } \\
\text { Belflower }\end{array}$ & $\begin{array}{l}\text { Private orchard } \\
\text { Wieprzkowicz, } \\
\text { Skierniewice }\end{array}$ & Oct. 10,1959 & \\
\hline IX & Starking & $\begin{array}{l}\text { Orchard of Pomological } \\
\text { Institute, Dąbrowice }\end{array}$ & Oct. 10,1959 & $\begin{array}{l}\text { intensely red; on the } \\
\text { side least exposed to } \\
\text { sunrays green patches } \\
\text { yellowing later }\end{array}$ \\
\hline
\end{tabular}

* Additional series included into experiment on Feb. 5, 1960; fruits somewhat larger than in series V (weight higher approximately about $35 \mathrm{~g}$ ).

AA extracts were prepared by grinding in a mortar the weighed samples with sand in a 1 per cent aqueous oxalic acid solution for $1 \mathrm{~min}$. (flesh, core) or $2 \mathrm{~min}$. (periphery). After leaving the extract to stand for 5 seconds (sedimentation of the sand), samples were taken for titration with sodium dichlorophenolindophenolate solution, $1 \mathrm{ml}$ of which corresponded to $0.066 \mathrm{mg}$ AA. The results are expressed as ppm of AA. 


\section{RESULTS}

A. Influence of storage on the AA levels in apples and on the configuration of the distribution gradient

During the period October 31, 1959 to May 17, 1960, sixty-eight apples belonging to 6 varieties were examined. In each fruit, determination of AA was performed in 20 cuts sliced along the ,diameter line” of the fruit, i. e. the line perpendicular to the fruit axis (stalk-sepals) at its middle point.

\section{AA distribution gradient typical for the apple}

The obtained diagrams of AA distribution along the ,diameter line" of the fruit are characteristic.

Figure 1 represents average results for all the examined fruits. The values given for each cut are averages calculated on the basis of average values for each variety for the whole storage period.

\section{AA distribution gradient characteristic fot the examined varieties}

The results of AA analysis for the stored apples are given separately for each serie in the Tables 2-10 (pp. 16-19). The AA distribution curves plotted on the basis of the obtained average values are - as may be seen from Fig. 2 - characteristic for each of the varieties studied.

Expressing the course of AA gradient distribution along the ,diameter line" of the apple by the following equation (2): $y=\left(\frac{D}{D-2 x}\right)^{2} \cdot a \cdot \mathrm{N} \log$ $(A-x \cdot E)$,

where:

$D$-- apple diameter

$x$ - distance of point on ,,diameter line" from surface in $\mathrm{mm}$

$\alpha$ - coefficient expressing the effect of irradiation in AA synthesis

$A$ - peripheral AA level

$E$ - extinction coefficient of parenchymal tissues

the particular varieties may be characterized in respect to $E$ and $\alpha$ values as follows:

\begin{tabular}{|l|c|c|c|}
\hline \multicolumn{1}{c|}{$\begin{array}{c}\text { Variety } \\
\text { No. }\end{array}$} & $\begin{array}{c}\text { Value } \\
, E,\end{array}$ & $\begin{array}{c}\text { Variety } \\
\text { No. }\end{array}$ & $\begin{array}{c}\text { Value } \\
, a,\end{array}$ \\
\hline VI, VII, V & \multirow{2}{*}{$\begin{array}{c}\text { V, VI, VII, VIII } \\
\text { VIII, I }\end{array}$} & $\begin{array}{c}\text { III, II, IX, I } \\
\text { order }\end{array}$ & $\begin{array}{c}\text { IV } \\
\text { Decreasing } \\
\text { order }\end{array}$ \\
\hline II, IX, III & & & \\
\hline IV & & & \\
\hline
\end{tabular}


The course of the curves for specimens of a given variety originating either from different size series (Nos. V and VI), or different orchards (Nos. I and II, VII and VIII) agree in general pretty well, in spite of certain differences in the degree of ripeness of the fruits or different dates of analysis.

It is worth attention that for some varieties the course of the curve in the medial part of the apple is specific. While for a number of varieties the curve descends gradually down to the fruit centre (most distinct in the Ontario variety), in others, particularly in the varieties Jonathan, or Yellow Belflower (Pepina Linneusza), owing to the higher AA level in the core, a small rise is seen in the centre.

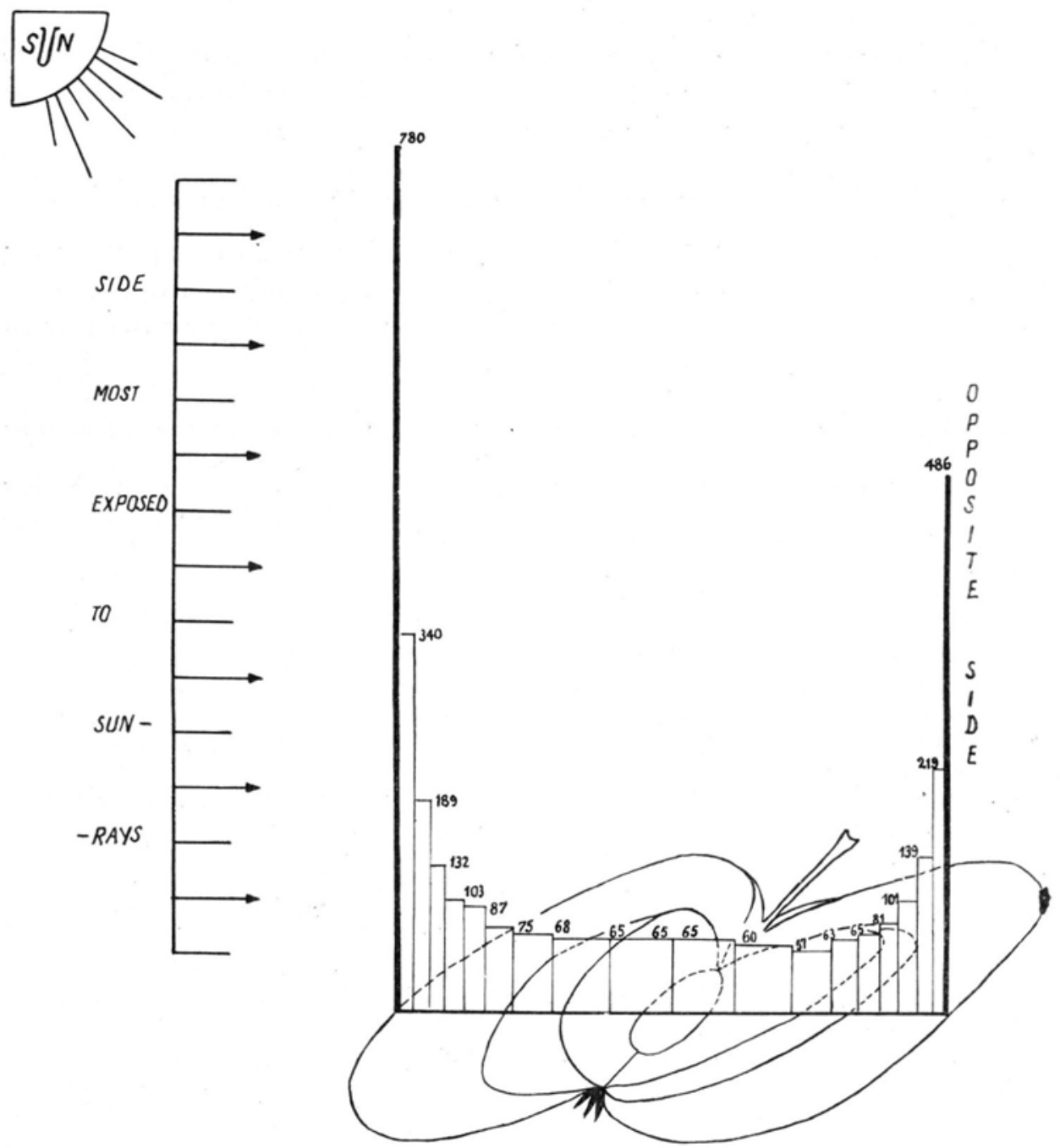

Fig. 1. Diagram of average AA levels for all 68 analyzed applefruits 


\section{Changes in $A A$ distribution gradient in different varieties in the course of storage}

The AA distribution pattern is preserved as a rule in apples of the studied varieties during the whole storage period. Nevertheless within one and the same variety the AA levels vary rather widely. The individual variability of the fruits plays here a certain role, although, as already said, when speaking of methods, the apples of each variety were selected for examination as uniform as possible in respect to size (see below point $B$ ) and degree of colouring, particularly of blush (see below point $C$ ). Chiefly, however, these variations seem to result from the fact that in a stored apple the AA content is a resultant of two different processes: AA synthesis* and ito decomposition**. This resultant effect is demonstrated in Fig. 3 on the example of the curves of the AA distribution gradient for the variety Yellow Belflower (No. VII), which shows changes in the AA levels in dependence on the month of storage***. In the period from November to January a distinct increase of the AA. level occurred, but in the subsequent months it was followed by a gradual fall. This temporary rise was also noted in the case of other varieties, e. g. Ontario, also in the period November - January, for the Boiken variety between November and March (the maximum level occurs earlier on the side most exposed to sunrays). In the variety Jonathan the maximum level occurs in late autumn (between November and December). The two varieties with the lowest AA content showed either a very small increase (var. Kitajka) or none at all (var. Starking).

Noteworthy is the particularly high AA level in the flesh of the last two apples of the Ontario variety analysed on May 9 and 10,1960, which towards the end of the storage period (May 4, 1960) were exceptionally (liquidation of storage chamber) transferred from a temperature of $4^{\circ}$ to $0^{\circ} \mathrm{C}$. The average AA contents - in the flesh cuts - calculated for both these apples are by 57 per cent higher on the average than in comparable cuts of an apple analysed directly before the transfer (May 4) and on the average by 45 per cent higher than the medium content in the flesh cuts of all the 7 previously analysed apples of this variety (from February 5, 1959 to May 4, 1960). It is worth noting that the rise of the AA level occurred in all the analysed sections (spedific gradation being preserved) with the exception of the periphery. The slight variations observed in the latter do not exceed the limits of experimental error.

* I. e. either by formation from its precursors, or by reduction of dehydroascorbic acid.

** To its degradation products in the sequence as fellow: dehydroascorbic acid, dicetogulonic acid, treonic and oxalic acids.

*** Weight losses as a result of transpiration, for apples of this variety amounted e. g. after 3 months of storage to only ca. 2 per cent and towards the end of the storage period (May) to ca. 6 per cent, thus it has been considered unnecessary to take them into account in calculating the results. 


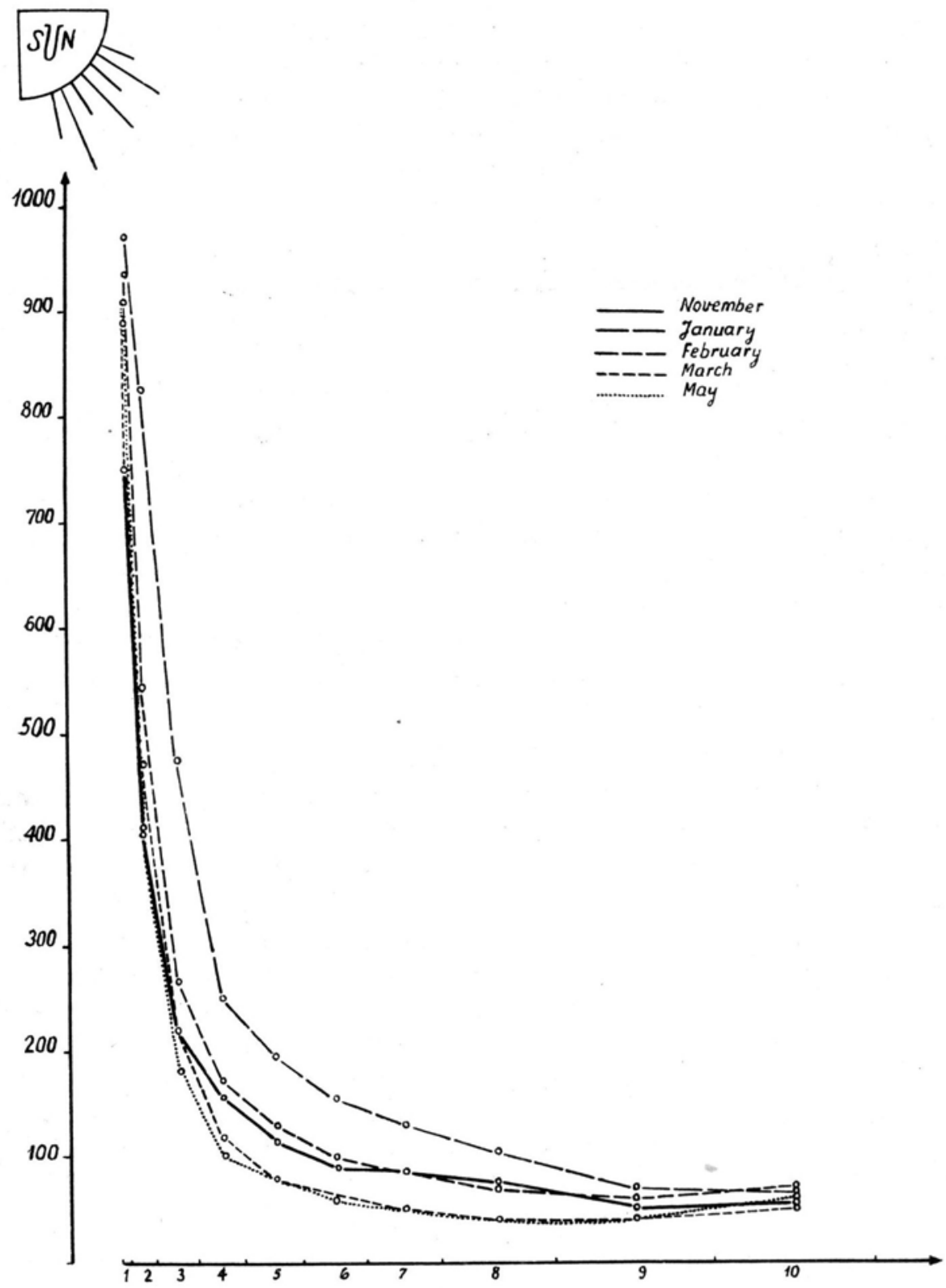

Fig. 3. AA levels in the most insolated part of the apple of the Pepina Linneusza variety at different storage periods 


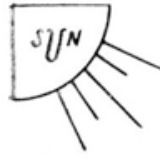

$1000 \quad$ apples $\left\{\begin{array}{l}A-(138 g)-15.11 .60 \\ B--(128 g)-19.11 .60 \\ C \cdots . .149 g)-5.11 .60\end{array}\right.$
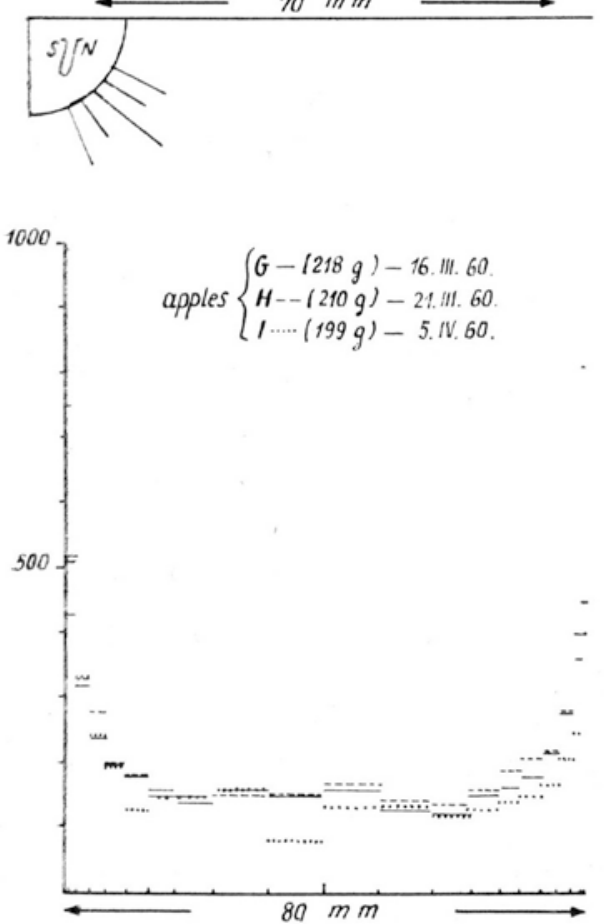
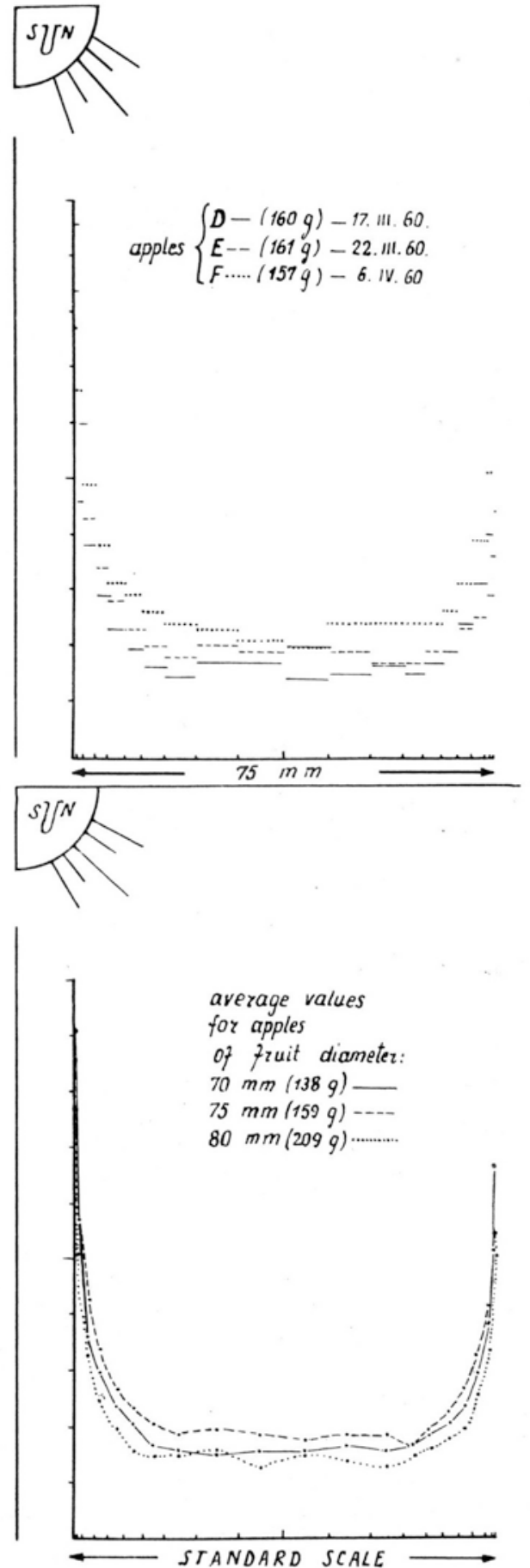

Fig. 4. AA levels in 9 apples of the Ontario variety belonging to 3 size classes. Vertical scales show concentrations of $\mathrm{AA}$ in ppm 

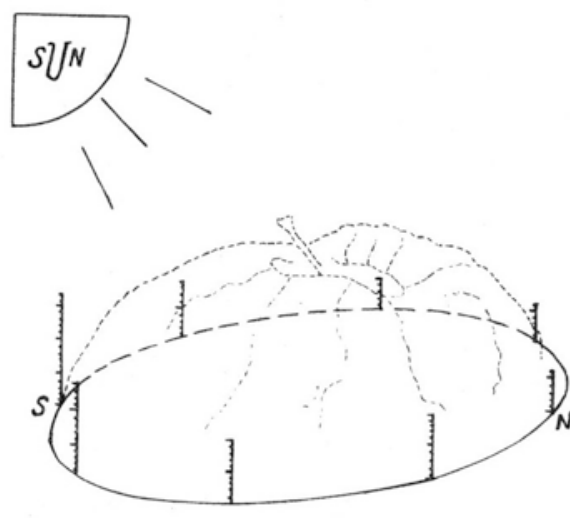

INIENSITY DEGREE OF RED COLOURATION OF APPLE FRUII (seen from the peduncle)
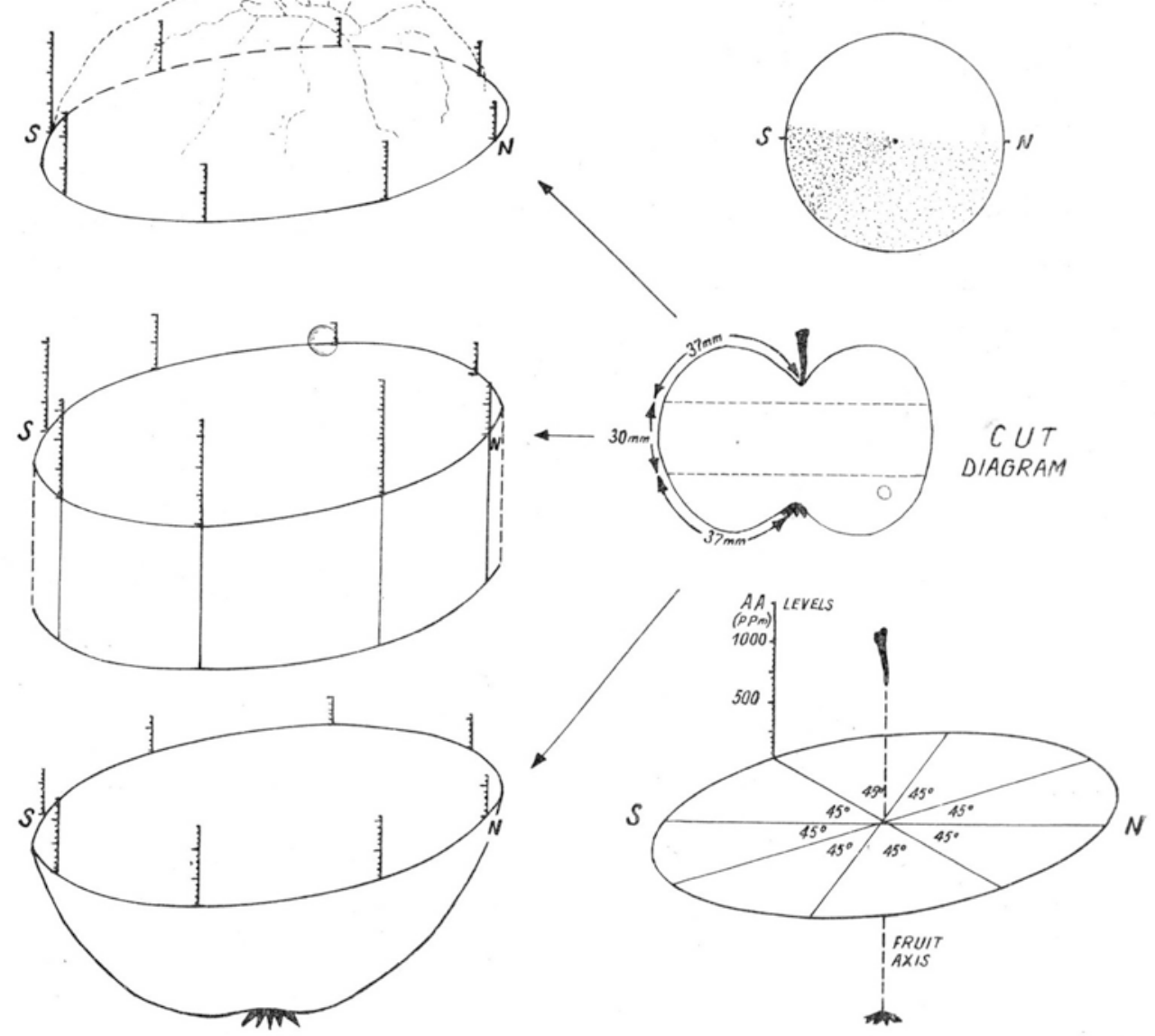

$75 \mathrm{~mm}$

Fig. 5. Distribution of $\mathrm{AA}$ in different zones of the Ontario apple periphery

B. Influence of the size of fruits on the AA levels along the „diameter line” In order to investigate this influence in the period March 15 - April 6, 1960, 9 apples of the Ontario variety were analysed, belonging to 3 size classes of the following diameters*: 70,75 and $80 \mathrm{~mm}$ of average weight 138 ,

* Typical for apples of both experimantal series. 
159 and 209 g, respectively. It was established (Fig. 4) that there exists no distinct relation between the size of the fruit and the AA levels along the „diameter line" in apples of this variety, though in general in larger specimens the AA content appears to be lower. This seems also to be confirmed by the higher AA level in the 3 smaller apples (av. weight $159 \mathrm{~g}$ ) of the Ontario variety, analysed in the series $\mathrm{V}$, as compared with that in the 3 larger apples (av. weight $195 \mathrm{~g}$ ) of the same variety belonging to series VI; all these specimens were analysed at a comparable date, i. e. the first half of February.

The relatively higher AA levels in smaller apples might perhaps be explained by easier transmission of the AA-forming rays into them, as compared with larger specimens. Since along the ,diameter line" the maximum levels lie in the peripheral layers and their ratio to the fruit mass is the higher, the smaller the apple, it may be surmised that smaller apples are as rule richer in AA than large ones.

\section{AA levels in the peripheral layer of the apple}

The AA levels in the peripheral layer were determined around the apple cross section in the defined zone as presented graphically in Fig. 5. The studies were carried out on apples of the Ontario variety, in which a thin uniform layer of "skin" is easily detached from the flesh. As may be seen in Fig. 5, the highest AA levels are found in the peripheral layer on the side with a blush which during the vegetation period was most exposed to sunrays. It is characteristic that the more intensive red pigmentation, the higher is the AA content.

\section{CONCLUSIONS}

1. The diagram of AA levels along the ,diameter line" of the apple is characterized by a specific gradient with some deviations for each of the studied varieties. The two following factors are no doubt in first place responsible for the occurrence of this gradient:

a) genetically conditioned varietal ability to synthesize AA;

b) degree of trasmittance of the AA-inducing rays through the coloured peripheral layer and the colourless flesh.

2. In the course of cold storage of apples the configuration of the typical AA distribution gradient practically remains unchanged. The theoretical and practical importance of this fact is more extensively considered in the discussion.

On the other hand the AA levels in apples change in the course of storage. In most of the examined varieties its rise is observed in the winter months, followed by a gradual fall. The AA content in stored apples should be considered as a resultant of two processes: AA synthesis and its decomposition. 
3. The increase of the AA level in stored apples during the winter months is easily explicable in association with their ripening*. On the other hand the rise of the AA content observed in apples of the Ontario variety after transfer towards the end of the storage period, from a temperature of $4^{\circ}$ to $0^{\circ} \mathrm{C}$, might perhaps be explained by the action of reduced temperature inducing AA formation in the period of accumulation of galacturonic acid (released in the process of breakdown of pectins), the derivatives of which may constitute A precursors.

\section{DISCUSSION}

The fact that the configuration of the AA distribution gradient is preserved in apples during storage may be interpreted both from the theoretical (a) and practical (b) aspect.

a. This phenomenon seems to confirm the hypothesis advanced by one of the present authors [4] that the A distribution gradient in the apple results rather from specific transmission of AA-forming rays into the fruit, than from diffusion of AA formed on the periphery into the deeper layers. If AA distribution were dependent on such diffusion, it could be expected that, in the course of long-lasting storage of the apples (consisting of living tissues), an equalization of the AA levels would take place.

b. The fall of the AA level in stored apples with simultaneous preservation of the gradient configuration of its distribution is a potential danger to the soundness of the fruit. As a result of the general decrease of the AA content, the central parts of the apple, poorest in this substance (particularly the flesh surrounding the core) may be completely deprived of AA. It is characteristic that it is in this region [3] that the first foci of browning appear which are a typical symptom of some storage diseases.

Basing on the knowledge of the varietal gradient and of the changes in the AA level in apples in the course of storage, it is possible to predict the approach of the critical moment for the given variety and to take action in time.

Research Institute of Pomology

(Entered: 23.X.1961)

Laboratory for Vitamin Assay

Skierniewice, Szeroka 19 Poland

* The possibility of the increase of the total AA content during the storage of immature apples was already annouced by $\mathrm{W}$ es $\mathrm{t}$ and $\mathrm{Zilva}(6)$ and recently by $\mathrm{S}$ toll et al. (5). 


\section{SUMMARY}

The diagram of as corbic a cid distribution in the apple tissues, cut in enfilade along the ,, diameter line" of the fruit, is characterized by a s p e c if i c g radie n t with some deviations for each of the studied varieties. In the course of cold storage of apples the configuration of this gradient practically remains unchanged, which seems to confirm the hypothesis that the ascorbic acid distribution in the apple results rather from specific transmission of ascorbic acid-forming rays into the fruit, than from diffusion of ascorbic acid formed on the periphery into the deeper layers.

On the other hand the a s corbic a cid $1 \mathrm{eve} 1 \mathrm{~s}$ in apple change in the course of storage as a result of two parallely occured processes: ascorbic acid synthesis (connected with ripening of the apples) and its decomposition. According to this which of these processes predominate, ascorbic acid levels rise or decrease.

\section{REFERENCES}

1. K. B o g d a ń s k i, 1960, Bull. Acad. Polon. Sci., Sér. sci. biol., 8: 189.

2. K. B o g d a ń s ki, 1961, The spatial distribution of ascorbic acid levels in flesh of fruits as a function of the light transmittance of tissues (in press).

3. K. B o g d a ń s k i, 1960. Bull. Acad. Polon. Sci., Sér. sci. biol., $8: 329$

4. K. B o g d a ń ski, H. W. B o g d a ń s ka, 1960, Bull. Acad. Polon. Sci., Sér. sci. biol., $8: 569$.

5. K. Sto 11, V. K o c h e r et al., 1958, Mitt. a. d. Gebiete d. Lebensm. und Hyg., $49: 172$.

6. C. W e s t, S. S. Zilva, 1944, Biochem. J., $38: 105$. 
Data for Boiken

\begin{tabular}{|c|c|c|c|c|c|c|c|c|c|c|c|}
\hline \multirow{3}{*}{ Analysis day } & \multirow{3}{*}{$\begin{array}{c}\text { Gramma- } \\
\text { ture } \\
\text { of ,„P”, }\end{array}$} & \multicolumn{10}{|c|}{ PPM of AA content in cuts lying in enfilade } \\
\hline & & \multicolumn{10}{|c|}{ Side exposed to sunrays } \\
\hline & & $1(\mathrm{P})$ & 2 & 3 & 4 & 5 & 6 & 7 & 8 & 9 & 10 \\
\hline 9.XI.59 & 400 & 110 & 40 & 20 & 20 & 20 & 20 & 10 & 10 & 20 & 30 \\
\hline 21.XI.59 & 300 & 280 & 100 & 70 & 50 & 30 & 30 & 20 & 20 & 20 & 30 \\
\hline 2.XII.59 & 400 & 320 & 150 & 80 & 50 & 40 & 30 & 30 & 25 & 30 & 10 \\
\hline 10.XII.59 & 550 & 300 & 170 & 90 & 60 & 50 & 40 & 30 & 20 & 25 & 10 \\
\hline 23.II.60 & 340 & 570 & 170 & 80 & 60 & 40 & 40 & 30 & 30 & 40 & 40 \\
\hline 26.II.60 & 270 & 530 & 200 & 130 & 80 & 60 & 50 & 40 & 40 & 40 & 45 \\
\hline 23.III.60 & 320 & 460 & 190 & 125 & 80 & 60 & 45 & 40 & 35 & 35 & 40 \\
\hline 31.III.60 & 340 & 370 & 120 & 60 & 40 & 30 & 30 & 25 & 30 & 40 & 40 \\
\hline 17.V.60 & 280 & 600 & 190 & 80 . & 50 & 40 & 30 & 30 & 40 & 50 & 60 \\
\hline Average: & 360 & 390 & 150 & 80 & 50 & 40 & 40 & 30 & 30 & 30 & 30 \\
\hline
\end{tabular}

Data for Boiken

\begin{tabular}{|c|c|c|c|c|c|c|c|c|c|c|c|}
\hline \multirow{3}{*}{ Analysis day } & \multirow{3}{*}{$\begin{array}{c}\text { Gramma- } \\
\text { ture } \\
\text { of ,,P”, }\end{array}$} & \multicolumn{10}{|c|}{ PPM of AA content in cuts lying in enfilade } \\
\hline & & \multicolumn{10}{|c|}{ Side exposed to sunrays } \\
\hline & & $1(\mathrm{P})$ & 2 & 3 & 4 & 5 & 6 & 7 & 8 & 9 & 10 \\
\hline 7.XI.59 & 400 & 470 & 130 & 60 & 40 & 30 & 30 & 20 & 10 & 15 & 20 \\
\hline 20.XI.59 & 500 & 570 & 200 & 80 & 50 & 30 & 20 & 20 & 20 & 20 & 0 \\
\hline 1.XII.59 & 400 & 340 & 200 & 90 & 50 & 40 & 30 & 30 & 25 & 25 & 15 \\
\hline 9.XII.59 & 400 & 630 & 380 & 160 & 90 & 60 & 50 & 40 & 30 & 30 & 30 \\
\hline 7.I.60 & 340 & 700 & 430 & 130 & 50 & 35 & 25 & 20 & 25 & 30 & 25 \\
\hline 21.I.60 & 280 & 650 & 230 & 80 & 50 & 30 & 20 & 20 & 20 & 30 & 10 \\
\hline 12.III.60 & 300 & 720 & 140 & 50 & 30 & 20 & 10 & 10 & 20 & 30 & 30 \\
\hline 4.IV.60 & 270 & 570 & 180 & 80 & 40 & 30 & 20 & 20 & 20 & 30 & 30 \\
\hline 11.V.60 & 310 & 420 & 130 & 70 & 40 & 20 & 20 & 20 & 20 & 30 & 40 \\
\hline Average: & 360 & 560 & 220 & 90 & 50 & 30 & 30 & 20 & 20 & 30 & 20 \\
\hline
\end{tabular}


ble 2

apples (serie I)

\begin{tabular}{|c|c|c|c|c|c|c|c|c|c|c|c|c|}
\hline \multicolumn{10}{|c|}{ Along the diameter line of the fruit } & \multirow{3}{*}{$\begin{array}{c}\text { Gramma- } \\
\text { ture } \\
\text { of ,,P” }\end{array}$} & \multicolumn{2}{|c|}{ Apple } \\
\hline \multicolumn{10}{|c|}{ Opposite side } & & Diame- & Weight \\
\hline 10 & 9 & 8 & 7 & 6 & 5 & 4 & 3 & 2 & $1(\mathrm{P})$ & & (in $\mathrm{mm}$ ) & \\
\hline 40 & 20 & 10 & 10 & 10 & 15 & 20 & 30 & 40 & 100 & 500 & 70 & 139 \\
\hline 25 & 25 & 20 & 20 & 20 & 30 & 40 & 60 & 80 & 300 & 300 & 70 & 145,5 \\
\hline 30 & 20 & 20 & 20 & 10 & 20 & 25 & 40 & 60 & 160 & 400 & 70 & 160 \\
\hline 30 & 30 & 20 & 20 & 20 & 30 & 30 & 50 & 80 & 260 & 400 & 65 & 135 \\
\hline 30 & 40 & 30 & 20 & 20 & 30 & 40 & 50 & 100 & 420 & 320 & 70 & 137 \\
\hline 30 & 40 & 40 & 30 & 30 & 40 & 60 & 80 & $16^{9}$ & 520 & 260 & 70 & 155 \\
\hline 30 & 25 & 25 & 20 & 20 & 20 & 30 & 40 & 70 & 240 & 330 & 65 & 131 \\
\hline 80 & 50 & 30 & 30 & 30 & 40 & 50 & 60 & 120 & 460 & 280 & 60 & 143 \\
\hline 45 & 40 & 25 & 20 & 20 & 30 & 40 & 60 & 110 & 440 & 300 & 55 & 127 \\
\hline 40 & 30 & 20 & 20 & 20 & 30 & 40 & 50 & 90 & 300 & 340 & 66 & 141 \\
\hline
\end{tabular}

ble 3

apples (serie II)

\begin{tabular}{|c|c|c|c|c|c|c|c|c|c|c|c|c|}
\hline \multicolumn{10}{|c|}{ Along the diameter line of the fruit } & \multirow{3}{*}{$\begin{array}{c}\text { Gramma- } \\
\text { ture } \\
\text { of ,,P”, }\end{array}$} & \multicolumn{2}{|c|}{ Apple } \\
\hline \multicolumn{10}{|c|}{ Opposite side } & & Diame- & Weight \\
\hline 10 & 9 & 8 & 7 & 6 & 5 & 4 & 3 & 2 & $1(\mathrm{P})$ & & (in $\mathrm{mm}$ ) & \\
\hline 20 & 10 & 5 & 5 & 5 & 10 & 10 & 20 & 30 & 130 & 400 & 75 & 150 \\
\hline 10 & 20 & 15 & 10 & 10 & 20 & 30 & 50 & 80 & 320 & 400 & 75 & 161,6 \\
\hline 15 & 25 & 20 & 20 & 20 & 20 & 30 & 40 & 70 & 220 & 400 & 70 & 146 \\
\hline 30 & 30 & 40 & 30 & 25 & 30 & 40 & 60 & 100 & 300 & 400 & 70 & 147,4 \\
\hline 25 & 30 & 20 & 20 & 15 & 20 & 30 & 60 & 180 & 390 & 320 & 70 & 149 \\
\hline 30 & 30 & 20 & 20 & 20 & 30 & 40 & 70 & 160 & 450 & 310 & 70 & 144 \\
\hline 30 & 30 & 20 & 10 & 10 & 20 & 30 & 70 & 150 & 450 & 310 & 60 & 132 \\
\hline 30 & 30 & 20 & 15 & 10 & 20 & 20 & 40 & 100 & 280 & 270 & 65 & 160 \\
\hline 45 & 35 & 25 & 15 & 10 & 10 & 20 & 40 & 100 & 280 & 310 & 75 & 153 \\
\hline 30 & 30 & 20 & 20 & 10 & 20 & 30 & 50 & 110 & 310 & 350 & 70 & 149 \\
\hline
\end{tabular}


Data for Jonathan

\begin{tabular}{|c|c|c|c|c|c|c|c|c|c|c|c|}
\hline \multirow{3}{*}{$\begin{array}{c}\text { Analysis } \\
\text { day }\end{array}$} & \multirow{3}{*}{$\begin{array}{c}\text { Gramma- } \\
\text { ture } \\
\text { of ,,P” }\end{array}$} & \multicolumn{10}{|c|}{ PPM of AA content in cuts lying in } \\
\hline & & \multicolumn{10}{|c|}{ Side exposed to sunrays } \\
\hline & & $1(\mathrm{P})$ & 2 & 3 & 4 & 5 & 6 & 7 & 8 & 9 & 10 \\
\hline 12.XI.59 & 300 & 1260 & 230 & 110 & 70 & 60 & 50 & 50 & 40 & 40 & 50 \\
\hline 23.XI.59 & 400 & 820 & 340 & 100 & 70 & 60 & 60 & 40 & 40 & 40 & 70 \\
\hline 3.XII.59 & 500 & 830 & 270 & 110 & 80 & 60 & 50 & 40 & 40 & 50 & 70 \\
\hline 12.XII.59 & 400 & 800 & 470 & 170 & 110 & 80 & 70 & 70 & 60 & 50 & 70 \\
\hline 9.I.60 & 310 & 750 & 360 & 120 & 60 & 50 & 40 & 40 & 30 & 30 & 40 \\
\hline 23.I.60 & 210 & 620 & 250 & 120 & 60 & 50 & 30 & 40 & 30 & 30 & 35 \\
\hline 4.IV.60 & 230 & 660 & 100 & 30 & 20 & 10 & 10 & 10 & 10 & 20 & 40 \\
\hline 13.V.60 & 220 & 760 & 150 & 60 & 30 & 25 & 20 & 20 & 20 & 20 & 30 \\
\hline Average: & 320 & 810 & 270 & 100 & 60 & 50 & 40 & 40 & 30 & 30 & 50 \\
\hline
\end{tabular}

$\mathrm{Ta}$

Data for Kitajka

\begin{tabular}{|c|c|c|c|c|c|c|c|c|c|c|c|}
\hline \multirow{3}{*}{$\begin{array}{l}\text { Analysis } \\
\text { day }\end{array}$} & \multirow{3}{*}{$\begin{array}{c}\text { Gramma- } \\
\text { ture } \\
\text { of ,,P', }\end{array}$} & \multicolumn{10}{|c|}{$\begin{array}{l}\text { PPM of AA content in cuts lying in } \\
\text { the }\end{array}$} \\
\hline & & \multicolumn{10}{|c|}{ Side exposed to sunrays } \\
\hline & & $1(\mathrm{P})$ & 2 & 3 & 4 & 5 & 6 & 7 & 8 & 9 & 10 \\
\hline 3.XI.59 & 500 & 410 & 40 & 15 & 10 & 10 & 0 & 0 & 0 & 5 & 10 \\
\hline 17.XI.59 & 300 & 530 & 80 & 40 & 20 & 20 & 20 & 15 & 14 & 20 & 20 \\
\hline 26.XI.59 & 570 & 540 & 130 & 40 & 30 & 20 & 20 & 20 & 10 & 10 & 10 \\
\hline 5.XII.59 & 460 & 540 & 90 & 25 & 15 & 5 & 10 & 10 & 5 & 14 & 10 \\
\hline 12.I.60 & 410 & 520 & 170 & 30 & 20 & 10 & 10 & 10 & 10 & 10 & 10 \\
\hline 26.I.60 & 330 & 580 & 70 & 10 & 0 & 0 & 0 & 5 & 0 & 0 & 0 \\
\hline 29.III.60 & 290 & 410 & 100 & 30 & 20 & 20 & 20 & 20 & 20 & 14 & 20 \\
\hline 6.V.60 & 360 & 230 & 60 & 30 & 20 & 20 & 10 & 15 & 10 & 15 & 5 \\
\hline Average: & 400 & 470 & 90 & 30 & 20 & 10 & 10 & 10 & 10 & 10 & 10 \\
\hline
\end{tabular}


ble 4

apples (serie III)

\begin{tabular}{|c|c|c|c|c|c|c|c|c|c|c|c|c|}
\hline \multicolumn{10}{|c|}{$\begin{array}{l}\text { enfilade along the diameter line of } \\
\text { fruit }\end{array}$} & \multirow{3}{*}{$\begin{array}{c}\text { Gramma- } \\
\text { thre } \\
\text { of ,,P” }\end{array}$} & \multicolumn{2}{|c|}{ Apple } \\
\hline \multicolumn{10}{|c|}{ Opposite side } & & Diame- & Weight \\
\hline 10 & 9 & 8 & 7 & 6 & 5 & 4 & 3 & 2 & $1(\mathrm{P})$ & & (in $\mathrm{mm}$ ) & (in g) \\
\hline 30 & 20 & 25 & 40 & 40 & 35 & 50 & 80 & 120 & 290 & 400 & 60 & 97 \\
\hline 50 & 40 & 30 & 30 & 25 & 30 & 40 & 70 & 90 & 320 & 300 & 60 & 110,6 \\
\hline 50 & 30 & 30 & 40 & 40 & 40 & 50 & 80 & 180 & 700 & 350 & - & 110,4 \\
\hline 45 & 40 & 40 & 40 & 40 & 60 & 70 & 110 & 220 & 780 & 300 & 60 & 105 \\
\hline 40 & 30 & 20 & 20 & 20 & 20 & 25 & 55 & 120 & 450 & 260 & 55 & 90 \\
\hline 30 & 20 & 10 & 10 & 10 & 10 & 20 & 50 & 150 & 790 & 180 & 65 & 124 \\
\hline 40 & 20 & 10 & 10 & 5 & 10 & 10 & 30 & 90 & 450 & 230 & 55 & 102 \\
\hline 30 & 20 & 10 & 10 & 10 & 10 & 10 & 30 & 90 & 260 & 300 & 60 & 100 \\
\hline 40 & 30 & 20 & 25 & 20 & 30 & 30 & 60 & 130 & 510 & 290 & 59 & 105 \\
\hline
\end{tabular}

ble 5

apples (serie IV)

\begin{tabular}{|c|c|c|c|c|c|c|c|c|c|c|c|c|}
\hline \multicolumn{10}{|c|}{$\begin{array}{l}\text { enfilade along the diameter line of } \\
\text { fruit }\end{array}$} & \multirow{3}{*}{$\begin{array}{c}\text { Gramma- } \\
\text { ture } \\
\text { of ,,P”, }\end{array}$} & \multicolumn{2}{|c|}{ Apple } \\
\hline \multicolumn{10}{|c|}{ Opposite side } & & Diame- & Weight \\
\hline 10 & 9 & 8 & 7 & 6 & 5 & 4 & 3 & 2 & $1(\mathrm{P})$ & & (in $\mathrm{mm}$ ) & (in g) \\
\hline 20 & 10 & 0 & 0 & 0 & 0 & 5 & 10 & 15 & 120 & 500 & 55 & 97 \\
\hline 10 & 10 & 5 & 10 & 10 & 10 & 10 & 10 & 30 & 250 & 400 & 60 & 106 \\
\hline 0 & 10 & 10 & 10 & 10 & 10 & 10 & 10 & 20 & 130 & 400 & 55 & 88,5 \\
\hline 10 & 10 & 5 & 5 & 0 & 0 & 0 & 0 & 10 & 110 & 300 & 55 & 100 \\
\hline 10 & 5 & 5 & 5 & 4 & 10 & 10 & 15 & 40 & 370 & 300 & 65 & 115 \\
\hline 5 & 10 & 0 & 0 & 0 & 0 & 0 & 0 & 10 & 60 & 240 & 60 & 101,2 \\
\hline 20 & 10 & 10 & 20 & 20 & 15 & 10 & 10 & 20 & 80 & 350 & 55 & 114 \\
\hline 10 & 10 & 10 & 10 & 10 & 10 & 20 & 20 & 10 & 70 & 520 & 50 & 102 \\
\hline 10 & 10 & 10 & 10 & 10 & 10 & 10 & 10 & 20 & 150 & 380 & 57 & 103 \\
\hline
\end{tabular}


Data for Ontario

\begin{tabular}{|c|c|c|c|c|c|c|c|c|c|c|c|}
\hline \multirow{3}{*}{$\begin{array}{l}\text { Analysis } \\
\text { day }\end{array}$} & \multirow{3}{*}{$\begin{array}{c}\text { Gramma- } \\
\text { ture } \\
\text { of ,,P”, }\end{array}$} & \multicolumn{10}{|c|}{ PPM of AA content in cuts lying in } \\
\hline & & \multicolumn{10}{|c|}{ Side exposed to sunrays } \\
\hline & & $1(\mathrm{P})$ & 2 & 3 & 4 & 5 & 6 & 7 & 8 & 9 & 10 \\
\hline 4.XI.59 & 500 & 1480 & 530 & 390 & 320 & 270 & 220 & 190 & 170 & 130 & 120 \\
\hline 18.XI.59 & 300 & 1310 & 430 & 310 & 230 & 180 & 160 & 140 & 160 & 120 & 110 \\
\hline 11.I.60 & 310 & 720 & 570 & 400 & 330 & 270 & 230 & 190 & 180 & 140 & 120 \\
\hline 25.I.60 & 210 & 1630 & 730 & 500 & 400 & 340 & 290 & 260 & 220 & 200 & 200 \\
\hline 4.II.60 & 190 & 1900 & 640 & 410 & 340 & 270 & 240 & 180 & 150 & 130 & 120 \\
\hline 13.II.60 & 320 & 1140 & 550 & 350 & 290 & 250 & 210 & 200 & 180 & 160 & 150 \\
\hline 15.II.60 & 250 & 1240 & 700 & 500 & 390 & 300 & 270 & 230 & 210 & 200 & 180 \\
\hline Average: & 300 & 1350 & 590 & 410 & 330 & 270 & 230 & 200 & 180 & 150 & 140 \\
\hline
\end{tabular}

Data for Ontario

\begin{tabular}{|c|c|c|c|c|c|c|c|c|c|c|c|}
\hline \multirow{3}{*}{$\begin{array}{l}\text { Analysis } \\
\text { day }\end{array}$} & \multirow{3}{*}{$\begin{array}{c}\text { Gramma- } \\
\text { ture } \\
\text { of ,,P”, }\end{array}$} & \multicolumn{10}{|c|}{$\begin{array}{r}\text { PPM of AA content in cuts lying in } \\
\text { the }\end{array}$} \\
\hline & & \multicolumn{10}{|c|}{ Side exposed to sunrays } \\
\hline & & $1(\mathrm{P})$ & 2 & 3 & 4 & 5 & 6 & 7 & 8 & 9 & 10 \\
\hline 5.II.60 & 290 & 1000 & 470 & 330 & 280 & 210 & 180 & 160 & 130 & 140 & 160 \\
\hline 6.II.60 & 260 & 1190 & 440 & 300 & 230 & 190 & 160 & 140 & 130 & 150 & 140 \\
\hline 11.II.60 & 300 & 1160 & 540 & 370 & 290 & 220 & 200 & 170 & 150 & 150 & 160 \\
\hline 24.II.60 & 290 & 1300 & 730 & 440 & 300 & 230 & 210 & 190 & 220 & 170 & 170 \\
\hline 29.II.60 & 240 & 1210 & 590 & 440 & 360 & 300 & 250 & 220 & 210 & 180 & 160 \\
\hline 24.III.60 & 260 & 1060 & 540 & 380 & 260 & 230 & 200 & 175 & 150 & 230 & 175 \\
\hline 4.V.60 & 250 & 980 & 460 & 350 & 310 & 230 & 190 & 160 & 150 & 155 & 140 \\
\hline 9.V.60 & 230 & 1040 & 860 & 580 & 430 & 340 & 300 & 270 & 230 & 250 & 230 \\
\hline 10.V.60 & 280 & 730 & 630 & 430 & 360 & 290 & 250 & 230 & 190 & 240 & 230 \\
\hline Average: & 270 & 1070 & 580 & 400 & 310 & 250 & 220 & 200 & 170 & 190 & 170 \\
\hline
\end{tabular}


ble 6

apples serie $\mathrm{V}$ )

enfilade along the diameter line of

fruit

\begin{tabular}{|c|c|c|c|c|c|c|r|r|r|r|r|r|}
\hline \multicolumn{10}{c|}{ Opposite side } & $\begin{array}{r}\text { Gramma- } \\
\text { ture } \\
\text { of ,P”, }\end{array}$ & $\begin{array}{c}\text { Diame- } \\
\text { ter } \\
\text { (in mm) }\end{array}$ & $\begin{array}{c}\text { Weight } \\
\text { (in g) }\end{array}$ \\
\hline 10 & 9 & 8 & 7 & 6 & 5 & 4 & 3 & 2 & $1(\mathrm{P})$ & & \\
\hline 100 & 120 & 130 & 140 & 160 & 180 & 210 & 350 & 340 & 780 & 400 & 70 & 145 \\
100 & 110 & 130 & 140 & 150 & 170 & 210 & 270 & 350 & 1040 & 350 & 75 & 163 \\
150 & 150 & 160 & 190 & 210 & 300 & 290 & 350 & 480 & 1070 & 210 & 75 & 152 \\
200 & 200 & 220 & 240 & 260 & 290 & 350 & 440 & 690 & 1090 & 200 & - & 177,7 \\
150 & 170 & 155 & 180 & 220 & 250 & 330 & 400 & 610 & 1160 & 240 & 70 & 153 \\
180 & 170 & 195 & 200 & 220 & 230 & 280 & 350 & 450 & 860 & 310 & 75 & 169 \\
180 & 180 & 170 & 180 & 180 & 190 & 230 & 280 & 350 & 390 & 350 & 70 & 156 \\
\hline 150 & 160 & 170 & 180 & 200 & 230 & 270 & 350 & 470 & 910 & 290 & 73 & 159 \\
\hline
\end{tabular}

ble 7

apples (serie VI)

enfilade along the diameter line of

fruit

\begin{tabular}{|l|c|c|c|c|c|c|c|c|c|c|c|c|}
\hline \multicolumn{10}{c|}{} & $\begin{array}{c}\text { Gramma- } \\
\text { ture } \\
\text { of ,P'” }\end{array}$ & $\begin{array}{c}\text { Diame- } \\
\text { ter } \\
\text { (in mm })\end{array}$ & $\begin{array}{c}\text { Wei- } \\
\text { ght } \\
\text { (in g) }\end{array}$ \\
\hline 10 & 9 & 8 & 7 & 6 & 5 & 4 & 3 & 2 & $1(\mathrm{P})$ & & & \\
\hline 160 & 140 & 155 & 175 & 190 & 220 & 270 & 340 & 430 & 640 & 300 & 75 & 181 \\
130 & 140 & 120 & 130 & 140 & 170 & 210 & 270 & 340 & 750 & 290 & 80 & 194 \\
160 & 160 & 150 & 170 & 190 & 220 & 280 & 360 & 500 & 950 & 310 & 80 & 211 \\
200 & 170 & 170 & 180 & 220 & 220 & 280 & 380 & 520 & 760 & 310 & 80 & 210 \\
140 & 120 & 110 & 120 & 140 & 160 & 200 & 260 & 340 & 830 & 240 & 70 & 192 \\
210 & 160 & 150 & 150 & 180 & 200 & 250 & 310 & 450 & 650 & 270 & 75 & 198 \\
110 & 160 & 140 & 150 & 150 & 180 & 220 & 280 & 370 & 750 & 280 & 75 & 185 \\
260 & 240 & 240 & 230 & 250 & 290 & 390 & 450 & 580 & 670 & 240 & 75 & 206 \\
200 & 200 & 190 & 230 & 250 & 300 & 360 & 460 & 660 & 900 & 230 & 70 & 169 \\
\hline 170 & 170 & 160 & 180 & 190 & 220 & 270 & 350 & 470 & 770 & 270 & 76 & 194 \\
\hline
\end{tabular}


$\mathrm{Ta}$

Data for Pepina Linne

\begin{tabular}{|c|c|c|c|c|c|c|c|c|c|c|c|}
\hline \multirow{3}{*}{$\begin{array}{c}\text { Analysis } \\
\text { day }\end{array}$} & \multirow{3}{*}{$\begin{array}{c}\text { Gramma- } \\
\text { ture } \\
\text { of ,,P”, }\end{array}$} & \multicolumn{10}{|c|}{ PPM of AA content in cuts lying in } \\
\hline & & \multicolumn{10}{|c|}{ Side exposed to sunrays } \\
\hline & & $1(\mathrm{P})$ & 2 & 3 & 4 & 5 & 6 & 7 & 8 & 9 & 10 \\
\hline 31.X.59 & 400 & 1050 & 400 & 240 & 150 & 120 & 100 & 90 & 100 & 50 & 40 \\
\hline 14.XI.59 & 300 & 740 & 280 & 160 & 110 & 80 & 60 & 60 & 60 & 40 & 50 \\
\hline 25.XI.59 & 300 & 760 & 530 & 280 & 200 & 150 & 120 & 110 & 90 & 60 & 60 \\
\hline 5.I.60 & 320 & 1000 & 830 & 360 & 250 & 200 & 160 & 130 & 90 & 60 & 50 \\
\hline 13.I.60 & 300 & 940 & 820 & 590 & 250 & 190 & 150 & 130 & 120 & 80 & 80 \\
\hline 22.II. 60 & 470 & 920 & 650 & 340 & 210 & 170 & 135 & 110 & 90 & 70 & 90 \\
\hline 25.II.60 & 240 & 950 & 440 & 190 & 130 & 90 & 70 & 60 & 50 & 50 & 50 \\
\hline 26.III.60 & 260 & 890 & 470 & 220 & 120 & 80 & 90 & 50 & 40 & 40 & 50 \\
\hline 5.V.60 & 220 & 910 & 410 & 180 & 100 & 40 & 60 & 50 & 40 & 40 & 60 \\
\hline Average: & 310 & 910 & 540 & 320 & 170 & 120 & 110 & 90 & 80 & 50 & 60 \\
\hline
\end{tabular}

$\mathrm{Ta}$

Data for Pepina Linne

\begin{tabular}{|c|c|c|c|c|c|c|c|c|c|c|c|}
\hline \multirow{3}{*}{$\begin{array}{l}\text { Analysis } \\
\text { day }\end{array}$} & \multirow{3}{*}{$\begin{array}{c}\text { Gramma- } \\
\text { ture } \\
\text { of , ,P', }\end{array}$} & \multicolumn{10}{|c|}{$\begin{array}{r}\text { PPM of AA content in cuts lying in } \\
\text { the }\end{array}$} \\
\hline & & \multicolumn{10}{|c|}{ Side exposed to sunrays } \\
\hline & & $1(\mathrm{P})$ & 2 & 3 & 4 & 5 & 6 & 7 & 8 & 9 & 10 \\
\hline 2.XI.59 & 500 & 1460 & 510 & 280 & 160 & 130 & 110 & 80 & 60 & 50 & 70 \\
\hline 16.XI.59 & 400 & 1100 & 420 & 220 & 150 & 110 & 100 & 90 & 80 & 50 & 55 \\
\hline 28.III.60 & 200 & 1370 & 660 & 310 & 200 & 140 & 110 & 80 & 60 & 65 & 80 \\
\hline Average: & 370 & 1310 & 530 & 270 & 170 & 130 & 110 & 80 & 70 & 60 & 70 \\
\hline
\end{tabular}

$\mathrm{Ta}$

Data for Starking

\begin{tabular}{|c|c|c|c|c|c|c|c|c|c|c|c|}
\hline \multirow{3}{*}{$\begin{array}{c}\text { Analysis } \\
\text { day }\end{array}$} & \multirow{3}{*}{$\begin{array}{c}\text { Gramma- } \\
\text { ture } \\
\text { of ,,P', }\end{array}$} & \multicolumn{10}{|c|}{ PPM of AA content in cuts lying in } \\
\hline & & \multicolumn{10}{|c|}{ Side exposed to sunrays } \\
\hline & & $1(\mathrm{P})$ & 2 & 3 & 4 & 5 & 6 & 7 & 8 & 9 & 10 \\
\hline 5.XI.59 & 400 & 570 & 170 & 80 & 60 & 40 & 30 & 20 & 20 & 20 & 20 \\
\hline 19.XI.59 & 400 & 830 & 240 & 130 & 80 & 60 & 40 & 30 & 20 & 20 & 40 \\
\hline 28.XI.59 & 500 & 500 & 190 & 80 & 40 & 30 & 20 & 20 & 20 & 20 & 20 \\
\hline 8.XII.59 & 500 & 490 & 160 & 60 & 40 & 30 & 20 & 20 & 10 & 10 & 10 \\
\hline 30.III.60 & 250 & 700 & 140 & 70 & 30 & 20 & 10 & 10 & 5 & 10 & 30 \\
\hline 7.V.60 & 290 & 500 & 100 & 40 & 10 & 10 & 0 & 0 & 0 & 5 & 10 \\
\hline Average: & 390 & 600 & 170 & 80 & 40 & 30 & 20 & 20 & 10 & 10 & 20 \\
\hline
\end{tabular}


ble 8

usza apples (serie VII)

\begin{tabular}{|c|c|c|c|c|c|c|c|c|c|c|c|c|}
\hline \multicolumn{10}{|c|}{$\begin{array}{l}\text { enfilade along the diameter line of } \\
\text { fruit }\end{array}$} & \multirow{3}{*}{$\begin{array}{c}\text { Gramma- } \\
\text { ture } \\
\text { of ,,P”, }\end{array}$} & \multicolumn{2}{|c|}{ Apple } \\
\hline \multicolumn{10}{|c|}{ Opposite side } & & \multirow{2}{*}{$\begin{array}{c}\text { Diame- } \\
\text { ter } \\
\text { (in } \mathrm{mm} \text { ) }\end{array}$} & \multirow{2}{*}{$\begin{array}{l}\text { Weight } \\
\text { (in g) }\end{array}$} \\
\hline 10 & 9 & 8 & 7 & 6 & 5 & 4 & 3 & 2 & $1(\mathrm{P})$ & & & \\
\hline 50 & 50 & 60 & 65 & 60 & 80 & 80 & 110 & 170 & 370 & 550 & 75 & 186 \\
\hline 40 & 40 & 60 & 70 & 70 & 80 & 100 & 140 & 220 & 370 & 400 & 75 & 198 \\
\hline 50 & 40 & 60 & 90 & 100 & 120 & 140 & 190 & 340 & 620 & 250 & 65 & 180 \\
\hline 50 & 40 & 55 & 80 & 90 & 110 & 140 & 200 & 310 & 510 & 250 & 70 & 192 \\
\hline 70 & 55 & 60 & 70 & 90 & 100 & 120 & 200 & 410 & 860 & 290 & 70 & 172 \\
\hline 70 & 50 & 40 & 70 & 80 & 90 & 100 & 180 & 310 & 450 & 410 & 75 & 188 \\
\hline 60 & 50 & 60 & 70 & 90 & 100 & 130 & 210 & 380 & 710 & 260 & 75 & 185 \\
\hline 40 & 40 & 30 & 45 & 50 & 70 & 80 & 130 & 280 & 460 & 280 & 70 & 217 \\
\hline 60 & 30 & 20 & 30 & 40 & 50 & 70 & 120 & 270 & 480 & 290 & 65 & 186 \\
\hline 50 & 40 & 50 & 70 & 70 & 90 & 110 & 160 & 300 & 540 & 330 & 71 & 189 \\
\hline
\end{tabular}

ble 9

usza apples (serie VIII)

enfilade along the diameter line of fruit

\begin{tabular}{c|r|r|r|r|r|r|r|r|r|r|r|r|}
\hline \multicolumn{7}{c|}{ Opposite side } & $\begin{array}{c}\text { Gramma- } \\
\text { ture } \\
\text { of ,,P” }\end{array}$ & $\begin{array}{c}\text { Diame- } \\
\text { ter } \\
\text { (in mm) }\end{array}$ & $\begin{array}{c}\text { Weight } \\
\text { (in g) }\end{array}$ \\
\hline 10 & 9 & 8 & 7 & 6 & 5 & 4 & 3 & 2 & $1(\mathrm{P})$ & & \\
\hline 70 & 55 & 55 & 70 & 85 & 100 & 120 & 170 & 280 & 600 & 500 & 70 & 198 \\
50 & 50 & 50 & 70 & 70 & 90 & 100 & 140 & 240 & 290 & 400 & 75 & 187 \\
90 & 70 & 70 & 90 & 110 & 120 & 170 & 240 & 480 & 860 & 330 & 60 & 167 \\
\hline 70 & 60 & 60 & 80 & 90 & 100 & 130 & 180 & 330 & 580 & 410 & 68 & 184 \\
\hline
\end{tabular}

ble 10

apples (serie IX)

\begin{tabular}{|c|c|c|c|c|c|c|c|c|c|c|c|c|}
\hline \multicolumn{10}{|c|}{$\begin{array}{l}\text { enfilade along the diameter line of } \\
\text { fruit }\end{array}$} & \multirow{3}{*}{$\begin{array}{c}\text { Gramma- } \\
\text { ture } \\
\text { of ,,P”, }\end{array}$} & \multicolumn{2}{|c|}{ Apple } \\
\hline \multicolumn{10}{|c|}{ Opposite side } & & Diame- & Weight \\
\hline 10 & 9 & 8 & 7 & 6 & 5 & 4 & 3 & 2 & $1(\mathrm{P})$ & & (in $\mathrm{mm}$ ) & \\
\hline 25 & 15 & 20 & 30 & 30 & 30 & 40 & 70 & 120 & 290 & 500 & 65 & 130 \\
\hline 30 & 20 & 20 & 20 & 30 & 40 & 60 & 90 & 180 & 530 & 500 & 60 & 119 \\
\hline 15 & 15 & 14 & 14 & 14 & 20 & 60 & 50 & 120 & 560 & 400 & 65 & 133,6 \\
\hline 10 & 10 & 10 & 15 & 20 & 20 & 30 & 50 & 90 & 260 & 300 & 65 & 131 \\
\hline 20 & 15 & 10 & 10 & 20 & 20 & 40 & 70 & 130 & 380 & 270 & 60 & 128 \\
\hline 20 & 10 & 0 & 0 & 0 & 0 & 5 & 20 & 90 & 380 & 370 & 55 & 120 \\
\hline 20 & 10 & 10 & 20 & 20 & 20 & 40 & 60 & 120 & 400 & 390 & 62 & 127 \\
\hline
\end{tabular}

